\title{
Protein Phosphatase 2A Subunit Gene
}

National Cancer Institute

\section{Source}

National Cancer Institute. Protein Phosphatase 2A Subunit Gene. NCI Thesaurus. Code C20396.

The Protein Phosphatase 2A Subunit Genes encodes 3 subunits (A, B, and C) of Protein Phosphatase 2A (PP2A) holoenzyme, a heterotrimeric serine/threonine phosphatase. The structural A subunit and the catalytic $C$ subunit form a catalytic core, while substrate specificity is directed by the B subunit. PP2A exerts regulatory control over the initiation of DNA replication and has a particularly complex set of regulatory subunits controlling its function and localization. 